\title{
Blood lipid of preadolescent boys of well-to-do families
}

\author{
Muzief Munir, Sudiro Darmoprawiro \\ Department of Child Health, Medical School, Trisakti University - Mintoharjo Naval Hospital, Jakarta
}

\begin{abstract}
Coronaty heart disease is presenlly one of the leading causes of death in adults in many countries, including in Indonesia. It is well known that elevated levels of cholesterol in children are closely associated with hypercholesterolemia and coronary heart disease in adull life. This study was conducted in an attempt to find a preliminary insight of the magnitude of the problem of hypercholesterolemia in children in Indonesia as a developing country. The blood lipid levels of 54 preadolescent boys from well-to-do families were analyzed. Two third of those children were shown to have elevated blood cholesterol level, and even one third or 16 out of 54 preadolescents boys investigated suffered from hypercholesterolemia. We conclude that elevated blood cholesterol level is frequently found among large-framed and obese Indonesian children. [Paedlatr Indones 2001;41:19-26]
\end{abstract}

Keywords: blood lipid level, cholesterol, preadolescent boys, coronary heart disease prevention

CORONARY HEART DISEASE IS THE LEADING CAUSE OF adUlt morbidity and mortality in the developed world. ${ }^{1}$ In Indonesia as a developing country, based on household surveys conducted by Department of Health in 1986 and 1992, in just six years the main cause of death shifted from diarrheal diseases in 1986 to cardiovascular diseases in 1992. It is also reported that the prevalence of coronary heart diseases (CHD) was found in younger ages. Although the etiology of $\mathrm{CHD}$ is multifactorial, one of the main risk factors for the development of coronary heart disease is high concentration of blood cholesterol, particularly the clevation of low density lipoprotein cholesterol (LDL. c), which is the leading cause of the development of a progressing process of atherosclerosis. ${ }^{1.7}$ Coronary atherosclerosis usually begins in early life, particularly in adolescence and young adults, and its effects continue to cumulate until adulthood. ${ }^{7.12}$ The

Correspondence: Professor Muzief Munir, MD, Department of Child Health, Medical School, Trisakti University, Jalan Kiai Tapa, Jakarta, Indonesia.
Bologusa heart study ${ }^{10}$ showed a positive correlation of LDL-c level with the degree of aortic wall involvement with fatty streaks: a group of children with cholesterol level between $140-170 \mathrm{mg} / \mathrm{dl}$ had approximately $25 \%$ involvement, while in a group with a level greater than $200 \mathrm{mg} / \mathrm{dl}$, the involvement was doubled. It is evident that high concentration of blood cholesterol and LDL-c during childhood leads to hypercholesterolemia in adulthood. In children with initial cholesterol levels greater than the 90th percentile in a single measurement, $43 \%$ were found to have levels greater than the 90 th percentile at 20 . 30 years of age, with $62 \%$ greater than the 75 th percentile and $81 \%$ greater than the 50 th percentile at adult ages. So that prevention of coronary heart disease in adulthood should start during childhood.

Hypercholesterolemia is closely associated with a high fat diet, low physical activity, familial history of myocardial infarction or familial high serum cholesterol, and smoking. ${ }^{13}$ Many risk factors might be responsible for the development of cardiovascular diseases in Indoncsia. These include cooking with tropical oils, smoking, little physical activity as the result 
of significant developments in communication and transportation technology, and the trend of increasing prevalence of obesity. This study was conducted in an attempt to secure a preliminary insight into the problem of hypercholesterolemia in preadolescent boys of well-to-do families in order that necessary measures could be undertaken at carlier ages to prevent coronary heart disease in the adult population.

\section{Methods}

Subjects for this study were 10-11 ycar old boys, selected randomly from Al Azhar clementary school, Kebayoran Baru, Jakarta, Indonesia. This was a private school mainly served the well-to-do families. Every child was asked not to take any food during the night and in the morning before having blood drawn for total cholesterol, LDL-c, HDL and triglyceride examinations. Body height and weight were measured to calculate body mass index as follows: $\mathrm{BMI}=$ weight in $\mathrm{kg} / \mathrm{h}$ cight in meters squarc. By using Canadian standards from the anthropometry report, ${ }^{14}$ the statures were grouped into, short (25th or less percentilc), medium (25-75thpercentile) and tall (75th percentile or more). Based on the body mass index, the studied population were grouped into: (1). Normal frame (BMI wab less than 90th percentilc; (2) Large frame or overweight (BMI was 90th percentile or more).

By using height and BMI the body form of children were divided into 6 groups:

1. Short with large frame (height, 25 th percentile or less, and BMI 90th percentilc or more)

2. Short with normal frame (height, 25 th percentilc or less, and BMI is less than 90th percentilc)

3. Medium with normal frame (height, 25-75th percentilc and BMI less than 90th percentile)

4. Medium with large frame (height, 25-75th percentile and BMI 90th percentile or morc)

5. Tall with normal frame (height, 75 th percentilc or more, and BMI less than 90th percentilc)

6. Tall with large frame (height, 75 th percentile or more, and BMI 90th percentilc or more)

Two measurements were taken for height and weight; a third measurement was required if the first two measurements differed by more than $0.5 \mathrm{~cm}$ for height and $0.3 \mathrm{~kg}$ for weight. The two measurements for height and weight were averaged, and if three measurcments were obtained, the two closest mea- surements were averaged. Body fat was demonstrated by measuring skin fold thickness with a Lange skinfold caliper at the triceps, subscapular, abdomen, and suprailiac sites, expressed in millimeters. Based on TSF thickness, body fat measurements were catcgorized into normal bosdy fat composition (TSF was 75th percentile of the standard for age), high risk for obesity (TSF was 75-90th percentile), and obcsc (TSF was more than 90th percentile of the standard).

Blood cholesterol levels werc grouped and defined as follows. Total blood cholesterol levels were considered: (1). Normal or acceptable total cholcsterol levels: total blood cholesterol less than $175 \mathrm{mg} /$ $\mathrm{dl}$; (2). Moderate clevated or high-risk-to-be hypercholesterolemia: total blood cholesterol between 175 . $200 \mathrm{mg} / \mathrm{dl}$; (3). High concentration or hypercholesterolemia: total cholesterol $175 \mathrm{mg} / \mathrm{dl}$ or morc. For LDL-c: (1). Normal or acceptable LDL-c concentration: LDL-c concentration of less than $110 \mathrm{mg} / \mathrm{dl}$; (2). Moderate elevated LDL-c concentration : LDL-c concentration of 110-129 mg/dl; (3). High concentration of LDL-c : LDL-c concentration of $130 \mathrm{mg} / \mathrm{dl}$ or morc.

Habitual physical exercisc was recorded by using a modificd instructive questionnaire of Godin and Shephard.15 Based on those questionnaires, the studied subjects were categorized into low-physical exercisc and high physical exercise groups.

\section{Results}

\section{Relationship of body frame and blood lipids}

Fifty-four boys were studued consisting of 24 normalframed (BMI less than 90th percentile), and 30 large frame children (BMI 90th percentile or more). The prevalence of high cholesterol level of more than 200 $\mathrm{mg} / \mathrm{dl}$ and elevated LDL-c of more than $110 \mathrm{mg} / \mathrm{dl}$ were significantly higher in large-framed children than those with normal frames, with the relative risk of hypercholestcrolemia of 1.1 in medium-framed and 1.9 in large-framed children. See Tables 1 and 2.

\section{Types of body fat and blood cholesterol}

The prevalence of high cholestcrol levels of more than $200 \mathrm{mg} / \mathrm{dl}$ and elevated LDL-c of more than $110 \mathrm{mg} /$ $\mathrm{dl}$ was significantly higher in obese than in non-obese children, with the relative risk of 1.6 in group of highrisk and was 2.85 in obese (Tables 3 and 4). 
TABLE 1. ASSOCIATION OF BODY MASS INDEX AND BLOOD CHOLESTEROL LEVEL

\begin{tabular}{|c|c|c|c|c|}
\hline \multicolumn{5}{|c|}{ Cholesterol } \\
\hline \multirow[b]{2}{*}{ BMI } & \multicolumn{4}{|c|}{ Elevated } \\
\hline & $\begin{array}{l}\text { Acceptable } \\
(<175 \mathrm{mg} \%)\end{array}$ & $\begin{array}{l}\text { Moderate elevated } \\
(175-200 \mathrm{mg} \%)\end{array}$ & $\begin{array}{l}\text { Hypercholesterolemia } \\
\text { (> } 200 \mathrm{mg} \% \text { ) }\end{array}$ & Total \\
\hline Normal frame & $14(50 \%)$ & $8(40 \%)$ & $2(10 \%)$ & 24 \\
\hline Big frame & $8(27 \%)$ & $8(27 \%)$ & $14(47 \%)$ & 30 \\
\hline Total & $22(41 \%)$ & $16(30 \%)$ & $16(30 \%)$ & 54 \\
\hline
\end{tabular}

TABLE 2. ASSOCIATION OF BODY MASS INDEX AND LDL LEVEL

\begin{tabular}{|c|c|c|c|c|}
\hline \multicolumn{5}{|c|}{ LDL } \\
\hline \multirow[b]{2}{*}{ BMI } & \multicolumn{4}{|c|}{ Elevated } \\
\hline & $\begin{array}{l}\text { Acceptable } \\
(<110 \mathrm{mg} / \mathrm{d} /)\end{array}$ & $\begin{array}{l}\text { Moderate elevated } \\
(110-129 \mathrm{mg} / \mathrm{dl})\end{array}$ & $\begin{array}{l}\text { High } \\
(>129 \mathrm{mg} / \mathrm{dl})\end{array}$ & Tota! \\
\hline Normal & $20(80 \%)$ & $2(10 \%)$ & $2(10 \%)$ & 24 \\
\hline Big frame & $11(37 \%)$ & $12(40 \%)$ & $7(23 \%)$ & 30 \\
\hline Total & $31(57 \%)$ & $14(26 \%)$ & $9(17 \%)$ & 54 \\
\hline
\end{tabular}

TABLE 3. ASSOCIATION OF BODY FAT APPEARANCE AND BLOOD CHOLESTEROL

\begin{tabular}{|c|c|c|c|c|}
\hline \multicolumn{5}{|c|}{ Cholesterol } \\
\hline \multirow{2}{*}{ Body fat } & \multicolumn{4}{|c|}{ Elevated } \\
\hline & $\begin{array}{l}\text { Acceptable } \\
(<175 \mathrm{mg} \%)\end{array}$ & $\begin{array}{l}\text { Moderate elevated } \\
(175-200 \mathrm{mg} \%)\end{array}$ & $\begin{array}{l}\text { Hypercholesterolemia } \\
(>200 \mathrm{mg} \%)\end{array}$ & Total \\
\hline Normal & $7(78 \%)$ & $2(22 \%)$ & . & 9 \\
\hline $\begin{array}{l}\text { Fatty (High risk } \\
\text { to be obese) }\end{array}$ & $6(50 \%)$ & $4(33 \%)$ & $2(17 \%)$ & 12 \\
\hline Obese & $9(27 \%)$ & $10(30 \%)$ & $14(32 \%)$ & 33 \\
\hline
\end{tabular}

TABLE 4. ASSOCIATION OF BODY FAT APPEARANCE AND LDL

\begin{tabular}{lcccr}
\hline \multicolumn{5}{c}{ LDL } \\
\hline \multirow{3}{*}{ Body fat } & \multicolumn{4}{c}{ Elevated } \\
\cline { 2 - 5 } & $\begin{array}{l}\text { Acceptable } \\
(<110 \mathrm{mg} \%)\end{array}$ & $\begin{array}{l}\text { Moderate elevated } \\
(110-129 \mathrm{mg} \%)\end{array}$ & $\begin{array}{l}\text { High } \\
(>130 \mathrm{mg} \%)\end{array}$ & Total \\
\hline Normal & 9 & - & - & 9 \\
Fatty & $9(75 \%)$ & $2(17 \%)$ & $1(8 \%)$ & 12 \\
Obese & $13(39 \%)$ & $12(36 \%)$ & $8(24 \%)$ & 33 \\
\hline
\end{tabular}

$X^{2}=13.3255 d f=4 \quad p<0.005$

TABLE 5. ASSOCIATION OF BLOOD LIPID AND BODY MASS INDEX (MEAN \pm SE)

\begin{tabular}{|c|c|c|c|}
\hline & $\begin{array}{l}\text { Normal Frame } \\
\text { ( }<90 \text { percentile) } \\
n=24\end{array}$ & $\begin{array}{l}\text { Big Frame } \\
\text { (>90 percentile) } \\
n=30\end{array}$ & 4 \\
\hline Total Cholesterol & $174.33 \pm 4.17$ & $195.73 \pm 4.66$ & $p<0.01^{*}$ \\
\hline LDL & $97.92 \pm 5.59$ & $118.20 \pm 4.30$ & $p<0.05^{n *}$ \\
\hline HDL & $56.29 \pm 2.37$ & $55.80 \pm 1.46$ & NS \\
\hline Triglyceride & $81.29+10.98$ & $114.47 \pm 13.47$ & NS \\
\hline
\end{tabular}


TABLE 6. RELATION OF BLOOD LIPID AND PHYSICAL SIZE (MEAN \pm SE)

\begin{tabular}{|c|c|c|c|c|c|c|}
\hline & \multicolumn{2}{|c|}{ Short } & \multicolumn{2}{|c|}{ Medium Migh } & \multicolumn{2}{|c|}{ Tall } \\
\hline & $\begin{array}{l}\text { Normal frame } \\
(n=9)\end{array}$ & $\begin{array}{l}\text { Big frame } \\
(n=6)\end{array}$ & $\begin{array}{l}\text { Normal frame } \\
(n=6)\end{array}$ & $\begin{array}{l}\text { Big frame } \\
(n=8)\end{array}$ & $\begin{array}{l}\text { Normal frame } \\
(n=9)\end{array}$ & $\begin{array}{l}\text { Big frame } \\
(n=16)\end{array}$ \\
\hline Tot. Cholesterol* & $\begin{array}{l}170.4 \pm 5 \\
(138-194)\end{array}$ & $\begin{array}{l}199.6 \pm 11.87 \\
(171-240)\end{array}$ & $\begin{array}{l}163.7 \pm 4.69 \\
(150-184)\end{array}$ & $\begin{array}{l}197.0 \pm 6.30 \\
(175-221)\end{array}$ & $\begin{array}{l}185.2 \pm 5.45 \\
(169-220)\end{array}$ & $\begin{array}{l}195.6 \pm 7.37 \\
(143-235)\end{array}$ \\
\hline LDL $^{* *}$ & $\begin{array}{l}93.2 \pm 6.78 \\
(60-127)\end{array}$ & $\begin{array}{l}121.6 \pm 11.27 \\
(95-162)\end{array}$ & $\begin{array}{l}87.8 \pm 5.93 \\
(65 \cdot 102)\end{array}$ & $\begin{array}{l}120 \pm 6.95 \\
(94-153)\end{array}$ & $\begin{array}{l}107.2 \pm 7.39 \\
(85-160)\end{array}$ & $\begin{array}{l}119.0 \pm 6.94 \\
(68-175)\end{array}$ \\
\hline $\mathrm{HDL} \#$ & $\begin{array}{l}58.9 \pm 3.03 \\
(45-69)\end{array}$ & $\begin{array}{l}57.6 \pm 1.03 \\
(54-60)\end{array}$ & $\begin{array}{l}54.5 \pm 3.15 \\
(44-63)\end{array}$ & $\begin{array}{l}54.0 \pm 2.08 \\
(43-75)\end{array}$ & $\begin{array}{l}54.0 \pm 2.08 \\
(47-63)\end{array}$ & $\begin{array}{l}56.8 \pm 1.90 \\
(36-69)\end{array}$ \\
\hline Triglyceride \# & $\begin{array}{l}68.2 \pm 11.97 \\
(39-170)\end{array}$ & $\begin{array}{l}90.2 \pm 14.60 \\
(54 \cdot 126)\end{array}$ & $\begin{array}{l}95.0 \pm 15.39 \\
(46-156)\end{array}$ & $\begin{array}{l}131.4 \pm 35.09 \\
(63-373)\end{array}$ & $\begin{array}{l}97.4 \pm 15.69 \\
(38-180)\end{array}$ & $\begin{array}{l}115.6 \pm 17.60 \\
(58-347)\end{array}$ \\
\hline
\end{tabular}

- Significant $(p<0.01) ; *$ Significant $(p<0.05) ;$ NS

TABLE 7. RELATION OF MEAN BLOOD CHOLESTEROL ANDTRICEPS SKIN FOLD

\begin{tabular}{|c|c|c|c|c|}
\hline & \multicolumn{4}{|c|}{ TSF } \\
\hline & $\begin{array}{l}\text { Normal } \\
\left(<75^{\text {th }} \text { percentile) }\right. \\
n=9 \\
\text { (mean \& SE) }\end{array}$ & $\begin{array}{l}\text { High risk to be obese } \\
\text { ( }<75-90^{4} \text { percentile) } \\
n=12 \\
\text { (mean } \pm \text { SE) }\end{array}$ & $\begin{array}{l}\text { Obese } \\
\text { (> 90 percentile) } \\
n=33 \\
\text { (mean } \pm \text { SE) }\end{array}$ & $\mathbf{p}$ \\
\hline Cholesterol Total & $\begin{array}{l}167.2 \pm 4.85 \\
(138 \cdot 185)\end{array}$ & $\begin{array}{l}179.7 \pm 5.54 \\
(160-220)\end{array}$ & $\begin{array}{l}193.7 \pm 4.39 \\
(143+235)\end{array}$ & $p<0.01^{\circ}$ \\
\hline LDL & $\begin{array}{l}88.9 \pm 5.27 \\
(60-104)\end{array}$ & $\begin{array}{l}103.7 \pm 7.16 \\
(65-160)\end{array}$ & $\begin{array}{l}111.7 \pm 4.36 \\
(68-175)\end{array}$ & $p<0.01$ \\
\hline HDL & $\begin{array}{l}57.7 \pm 3.38 \\
(44-73)\end{array}$ & $\begin{array}{l}56.9 \pm 1.88 \\
(46 \cdot 68)\end{array}$ & $\begin{array}{l}55.4 \pm 1.36 \\
(36-75)\end{array}$ & NS \\
\hline Triglyceride & $\begin{array}{l}83.8 \pm 12.96 \\
(39-170)\end{array}$ & $\begin{array}{l}77.0+10.45 \\
(38-159)\end{array}$ & $\begin{array}{l}112.0 \pm 12.56 \\
(52 \cdot 373)\end{array}$ & NS \\
\hline
\end{tabular}

\section{Blood cholesterol and physical size}

Table 5 shows that the mean total cholesterol and LDL $-c$ levels of large frame pre-adolescent boys were significantly higher than those in normal and medium frames. The mean blood cholesterol in large frames was $195.7 \mathrm{mg} / \mathrm{dl}$, in medium and small frames it was $178.0 \mathrm{mg} / \mathrm{dl}$ and $155.8 \%$, respectively. W/hile the mean concentration of LDL-c in large frames was $118.2 \mathrm{mg} /$ $\mathrm{dl}$, and in medium and small frames it was $101.8 \mathrm{mg} /$ $\mathrm{dl}$ and $78.3 \mathrm{mg} / \mathrm{dl}$, respectively. Table 6 shows that the mean total cholesterol and LDL $c$ in tall, normal height an short large frames were significantly higher than those in normal frames. The highest concentration of cholesterol and LDL $\mathrm{c}$ was found in short large frame children with their mean concentration of 199.6 $\mathrm{mg} / \mathrm{dl}$ and $121.6 \mathrm{mg} / \mathrm{dl}$ respectively.
Table 7 shows that the mean total cholesterol of $193.8 \mathrm{mg} / \mathrm{dl}$ and $111.7 \mathrm{mg} / \mathrm{dl}$ of LDL-c in a obese children was significantly higher than that of, respectively, $167.2 \mathrm{mg} / \mathrm{dl}$ and of $88.9 \mathrm{mg} / \mathrm{dl}$ in normal reference children.

Table 8 shows that the mean total cholesterol and LDL-C in obese short, medium and tall children were significantly higher than that in non-obese. However, the mean total cholesterol of $186.8 \mathrm{mg} / \mathrm{dl}$, and LDL-C of $112 \mathrm{mg} / \mathrm{dl}$ in normal tall children were the concentration levels of high risk to develop atherosclerosis.

Table 9 shows that the mean total cholesterol and LDL-c in both large and normal frames of low activity children were significantly higher than that in those of high physical activity. The mean total cho- 
TABLE 8. RELATION OF MEAN BLOOD CHOLESTEROL AND BODY FORM

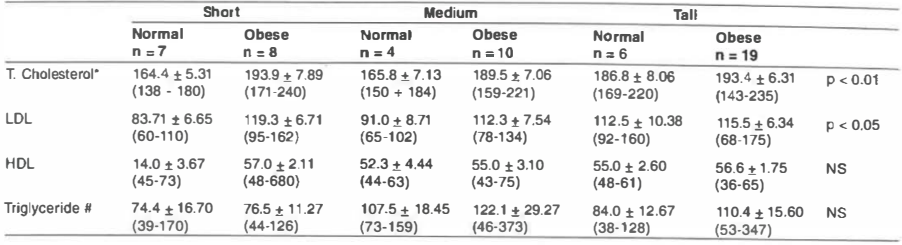

TABLE 9. AELATION OF BLOOD LIPID AND DAILY PHYSICAL ACTIVITY

\begin{tabular}{|c|c|c|c|c|c|}
\hline & \multicolumn{2}{|c|}{ Less active with } & \multicolumn{2}{|c|}{ active with } & \multirow[b]{2}{*}{$\mathbf{p}$} \\
\hline & $\begin{array}{l}\text { Normal frame } \\
n=10\end{array}$ & $\begin{array}{l}\text { Big frame } \\
n=12\end{array}$ & $\begin{array}{l}\text { Normal frame } \\
n=15\end{array}$ & $\begin{array}{l}\text { Big frame } \\
n=17\end{array}$ & \\
\hline T. Cholesterol* & $\begin{array}{l}177.6 \pm 2.90 \\
(164 \cdot 200)\end{array}$ & $\begin{array}{l}205.4 \pm 6.74 \\
(165-235)\end{array}$ & $\begin{array}{l}171.7 \pm 5.23 \\
(138+220)\end{array}$ & $\begin{array}{l}190.7 \pm 6.25 \\
(143-240)\end{array}$ & $p<0.01$ \\
\hline LDL & $\begin{array}{l}99.3 \pm 3.77 \\
(79-122)\end{array}$ & $\begin{array}{l}124.7 \pm 5.37 \\
(94-153)\end{array}$ & $\begin{array}{l}95.4 \pm 6.67 \\
(60-160)\end{array}$ & $\begin{array}{l}116.2 \pm 6.80 \\
(68-175)\end{array}$ & $p<0.01$ \\
\hline $\mathrm{HDL}$ & $\begin{array}{l}58.8 \pm 1.58 \\
(52-69)\end{array}$ & $\begin{array}{l}56.0 \pm 2.40 \\
(36-69)\end{array}$ & $\begin{array}{l}54.8 \pm 2.49 \\
(44-73)\end{array}$ & $\begin{array}{l}56.5 \pm 1.83 \\
(45-75)\end{array}$ & NS \\
\hline Triglyceride \# & $\begin{array}{l}77.1 \pm 8.69 \\
(38-128)\end{array}$ & $\begin{array}{l}137.3 \pm 21.41 \\
(59-347)\end{array}$ & $\begin{array}{l}82.2 \pm 11.32 \\
(39-170)\end{array}$ & $\begin{array}{l}102.0 \pm 17.68 \\
(54-373)\end{array}$ & NS \\
\hline
\end{tabular}

lesterol of low physical activity was $205.42 \mathrm{mg} / \mathrm{dl}$ comparing to $190.47 \mathrm{mg} / \mathrm{dl}$ for large frame high physical activity children.

\section{Discussion}

Surprisingly, one third or 16 out of 54 (30\%) preadolescent boys of well-to-dofamilies in our studies were hypercholesterolemic with a total blood cholesterol of $200 \mathrm{mg} / \mathrm{dl}$ or more, and almost another one third or 15 of those subject studies were high risk hypercholesterolemia. It is widely well accepted that children with blood cholesterol of more than $175 \mathrm{mg} /$ $\mathrm{dl}$ should be treated as elevated levels of blood cholesterol and should be followed up routinely during their life. These findings were much higher than those reported from Western World, where the prevalence of hypercholesterolemia in children was less than $10 \%$ and only one fourth had cholesterol level more than
$175 \mathrm{mg} / \mathrm{dl} .{ }^{5.6}$ Since LDL-c is closely related to atherosclerosis, the elevation of LDL is a more important indicator in the development of cardio-vascular diseases. Nearly half of our subject studies or 23 out of 54 showed an elevation of LDL, even 9 of them with high concentration of more than $130 \mathrm{mg} / \mathrm{dl}$. These children if not treated now, many years later during their adulthood will suffer from cardiovascular diseases since $\mathrm{LDL}_{-}-\mathrm{c}$ and $\mathrm{HDL}-\mathrm{c}$, and their risks were affected by a number of life styles, including of obesity, level of exercise, cigarette smoking, and also alcohol consumption.

Since our findings showed that the prevalence of hypercholesterolemia and high concentration of cholesterol of more than $175 \mathrm{mg} / \mathrm{dl}$ were high among preadolescent boys of well-to-do families, early identification of children with a high risk of hypercholesterolemia followed by nutritional and medical interventions are very important efforts to prevent future 
coronary heart discase. Garcia and Moodie (1989) based on their findings, suggested that all children over 3 ycar of age should have a routine cholesterol test in an cffort to avoid a high-risk coronaty life style behavior during their further life. ${ }^{14}$ However, due to medical and technical disadvantages and limitations, it is not rational to recommend for routine blood cholesterol examination to all Indonesian preadolescents boys. High cost, lack of laburatory facilities, poor laboratory standardizations, and diurnal and scasonal effects on blood cholesterol, are among those disadvantages and limitations.

It has been recommended to screen for high cholesterol levels only in children with a family history of hypercholesterolemia or coronary heart disease. ${ }^{17-18} \mathrm{On}$ contrary, Wong et al ${ }^{19}$ reported controversial findings that there was no association of parent or grandparent history of premature myocardial infarction with a child's cholesterol level, but a positive family history of a high cholesterol level was modestly associated with an increased probability of having high cholesterol level with a relative risk of 1.6 . It was proved that due to strict criteria limited to those with a positive family history as the only indicator, many children with clcvated cholesterol valucs are missed, and during their adult life suffer from coronary heart disease. ${ }^{20.21}$ A flexible and broader criteria for screening hypercholesterolemia is needed to avoid uncovered cases.

Physical appearances such as body fatness and BMI can be used as one of the screening criteria for routine detection of hypercholesterolemia. Based on population studies of children and adolescents, excess subcutaneous fatness was associated with elevated blood pressurc, serum lipids and lipoprotein fraction. ${ }^{22-25}$ Obesity is known as the most prominent coronary heart disease risk factor since obese adolescent have a high incidence of multiple coronaty heart discase risk. On the other hand obesity is also an independent risk factor for $\mathrm{CH}$ ID, as the correlation of obesity and CHD is independent of age, serum cholesterol, blood pressure, cigarette smoking, or glucose intolerance. ${ }^{26} \mathrm{By}$ using body fat patterns, our findings showed that the prevalence of hypercholesterolemia, a and high concentration of LDL-C in obese subjects were significantly higher than those in normal nonobese. The mean blood cholesterol and LDL-c in obese particularly in short obese subjects were significantly higher than those in non obese, and they were much higher than their 75th percentiles.

Since our findings also showed that in tall-nonobese subjects the mean total cholesterol and LDL-c were much higher than those of their 75 th percentile, $175 \mathrm{mg} / \mathrm{dl}$ for total cholesterol and $110 \mathrm{mg} / \mathrm{dl}$ for LDL-c, a tall non-obese could also be included as risk factur in the development of coronary heart disease in their futurc life. As in obese subjects, the mean total blood cholesterol of and LDL-c in large frame or overweight, particularly in short overweight subjects with total blood cholesterol of $199.6 \mathrm{mg} / \mathrm{dl}$ and with LDL-c of $121.6 \mathrm{mg} / \mathrm{dl}$ were significantly higher than those in normal frame, and they were much higher than the level of their 75 th percentile. In a tall normal frame the mean total cholesterol and LDL-c concentration were normal, below their 75 th percentile.

It is well known that physical activities, defined as any bodily movement that results in energy expenditure in adult and adolescent, determine blood cholesterol concentration particularly increasing $\mathrm{HDL}-\mathrm{c}$ concentration. ${ }^{27}$ Since different methods of assessing children's physical activitics, the effects of physical activitics on blood cholesterol are controversial. Only few studics have been conducted regarding the cffect of physical exercisc, or habitual physical activity, or both on serum lipid and lipoprotein levels. Whereas Thorland and Gillian ${ }^{28}$, Yamamoto $\mathrm{et} \mathrm{al}^{{ }^{29}}$ and Macek et al ${ }^{30}$ reported there was a direct association between physical activity and HDL concentration, Sallis et $\mathrm{al}^{31}$ reported no effect. Our findings based on structured. interview-method showed that total cholesterol and LDL- $c$ in normal frame and in large frame or overweight subjects of less active subjects were significantly higher than those physically active subjects. But the concentration of HDL-c and triglyceride did not show statistically different between less active and active subjects (Table 9).

The vast majority of less active subjects spent their time through watching television. Watching television is definitely one kind of low physical activity and duration of television watching is found to be onc of the predictors for elevated blood cholesterol in children. Wrong et al also reported that excessive television watching of more than 4 houts per day showed to be a strongest predictive screen for elevated cholesterol values of $200 \mathrm{mg} / \mathrm{dl}$ or more with a relative risk of 4.8 and 2.2 if television is watched $2-4$ hours per day when compared to those watching less than 
two hours per day. Our findings have clearly shown that adolescent children who had with low physical activitics had a significantly higher cholesterol and L.DL-c levels than those children with high physical activities.

We conclude that a significant percentage of preadolescent boys of wcll-to-do families in Jakarta are found to have a moderate and high level of blood cholesterol. Surprisingly, the figure in fact is much higher than that repurted from studics in developed countries. In attempt to find out the magnitude prob. lems of coronary heart disease risk factors in Indonesian community, it is necessary to conduct studies in Indoncsian communities with their difference grounds.

\section{References}

1. Kannel WB, Doyle JT, Ostfeld AM et al. Optimal resources for primary prevention of atherosclerotic diseases. Circulation 1984;70:155A-205A.

2. Keys A, Taylor HL, Blackburn $\mathrm{H}$ et al. Mortality and coronary heart disease among men studicd for 23 years. Arch lnt Med 1971;128:201-4.

3. Tyroler HA, Heyden S, Bartel A et al. Blood pressure and cholesterol as coronary heart disease risk factors. Arch Int Med 1971; 128:907-14.

4. Kannel WB, Castelli WP, Gordon $T$ et al Serum cholesterol, lipoproteins and risk for coronaty heart disease. The Framingham study. Ann Int Med 1971;74:1-12.

5. Keys A, Aravanis $\mathrm{C}$, Blackburn $\mathrm{H}$ et al. Probability of middle age men developing coronary heart disease in five years. Circulation 1972:45:815-28.

6. Kannel WB. The role of cholesterol in atherogenesis. Mcd Clin North Am 1974:58:363-79.

7. McGill HC Jr. Fatty streaks in the coronary arteries and aorta.J lab lnvest 1968;18:560-4

8. Nader PR, Taras HL, Salis JF, Patterson TL. Adult heart disease prevention in childhood: a national survey of paediatrician's practices and attitudes. Pediatrics 1987; 79:843-50.

9. Newman WP, Freedman DS, Voors AW et al Relationship of serum lipoprotein levels and systolic blood pressurc to early atherosclerusis. The Bogalusa l leart Study. New Engl Med 1986;314:138-44.

10. Lauer RM, Lee J, Clarke WR. Factors affecting the relationship hetween childhood and adult cholesterol levels. The Muscatine study. Pediatrics 1988;82:309-18.

11. Lee J, Iauer RM, Clark WR. Lipoprotcin in the progeny of young men with coronary artery disease. Children with increase risk. Pediatrics 1986, 8:330-7.
12. Laskarzewski P, Morison JA, de Groot I et al. Lipid and lipoprotein tracking in 108 children over a four-year-period. Pediacrics 1986,78:330-7.

13. Craig WY, Palomaki GE, Johnson AM, Haddow JE. Cigarette smoking-associated changes in blood lipid and lipoprotein levels in the 8-10 19-year old group. A metaanalysis. Pediatric 1990,85:155-8.

14. Rosaline S Gibson. Principles of nutritionassessment. OxfordUniversity Press 1990.

15. Godin G, Shephard RJ. A simple method to assess exercise bahavior in the community. Can J Appl Sport Sci 1985;3:141-6.

16. Garcia RE, Moodie DS. Routine cholesterol surveilance in childhood. Pediatrics 1989,84:751-5.

17. Goff DC Jr, Donker Ge A, Ragan JD Jr. Cholesterol screening in pediatric practice. Pediatrics $1991 ; 88: 250-8$.

18 American Academy of Pediatrics, Committee on $\mathrm{Nu}$ trition, Indicatious for cholesterul testing in childiren. $\mathrm{Pe}$ diatric 1989;83:141-2.

19. Wong ND, Hei TK, Qaqundah Py ct al. Television viewing and pediatric hypercholesterolemia. Pediatrics 1992; 90:75-9.

20. Myerson UA, Santanello NC. Pediatric lipid screening based on criteria of high risk fanily histony fails to identify two-thirds of high risk children. Circulation 1988; 78:382.

21. Khoury P, Morison JA, Kelly K, Meilies M, Horvitz R, Glueck CJ. Clustering and interrelationship of coronary heart disease tisk farctors in schrol children, age 6-19. Am J Epidenuol 1980;112:524-38.

22. Freedman DS, Burke GL, Harsha DW et al. Relationship of changes in obesity to serum lipid and lipoprotein changes in childhood and adolescence. JAMA 1985; 254:515-20.

23. Smoak CG, Burke GL, Webber LS, Harsha DW, Srinivasan SR, Berenson GS. Relation of obesity tu clustering of cardiovascular disease risk factors in children and youngadults. Am J Epidemicol 1987;125:364-72.

24. Wattigney WA, Harsha DW, Srinivasan SR, Webber LS, Brenson GS. Increasing impact of obesity on scrum lipids and lipoproteins in young adults. The Bologusa heart study. Arch lntern Mod 1991;151:2017-22.

25. Williams DP, Going SB, Lohman TG, et al. Botly fatness and risk for elevatei blexd pressure,

senum lipoprotein ratios in children and adolescents. Am J Publ Hith 1992;82:358-63.

26. Hubert HB, Feinley M, McNamara PM, Castell WP. Ohesity as independent risk factor for cardiovascular dis. ease: A 26-ycar follow-up of participxints in the Framing dh:am Hearr Study.Circulation 1983;67:968-77.

27. Craig SB, Bandini LG, Lichtenstein S, Schacfer EJ, Dietz WH. Impact of physicial activity on lipas, lipoprostein, and blood prssure in preadolescent girls. Pediatrics 1996;98:389-95. 
28. Thorlan WC, Gillaim TB. Comparison of serum lipids between habitually high and low active preadolescent males. Med SciSportExerc 1981; 13:316.

29. YamamotoA, Horibe $\mathbf{H}$, Sawada $\mathrm{S}$, et al. Serum lipid level in elementary and junior high school children and their relationship to relative weight. Pre Med 1988; 17:93. 108.
30. Macek M, Bell D, Rutenfranz J, et al. A comparison of coronaty risk factors in groups of trained and untrained adolescents. Eur J App Physiol 1989; 58:577-82.

31. Salls JF, Patterson TL, Buono MJ, Nader PE. Relation of cardiovascular fitness and physical activity to cardiovas. cular disease and risk factors in children and adult. Am j Epidemiol 1998; 127:933-41. 